\title{
O MENINO-POETA: NO OLHAR OBLÍQUO, A POESIA
}

Leandro DURAZZO ${ }^{115}$

Kelcilene GRÁCIA-RODRIGUES ${ }^{116}$

BARROS, M. de. Menino do mato. São Paulo: Leya, 2010.

A função prática da linguagem é comunicar, dar ao homem óculos para que enxergue o mundo, de forma que compreenda o que ele próprio pensa sobre a realidade que o circunda. Na poesia de Manoel de Barros, a visão não se põe entendível. Antes, o menino do mato desvê as coisas, a natureza, a existência, e desvendo tudo desvenda os elementos que adultos não podem alcançar.

Em seu mais recente livro de poemas, Menino do mato (2010), Manoel de Barros nos ensina como aprendeu a desaprender, quando criança, vivendo entre formigas e animais do brejo. $\mathrm{O}$ tom recordatório surge já na abertura da primeira parte do livro, "queria usar palavras de ave para escrever", e perpassa todo o volume. Também está presente nesta primeira parte - efetivamente "Menino do mato", enquanto a segunda se intitula "Caderno de aprendiz" —, possivelmente, o "método" de escrita que Manoel de Barros tirou da natureza. Ou, mais precisamente, o método que comungou com ela.

São seis poemas nessa primeira parte, e eles parecem apresentar os momentos iniciais de consciência poética do menino, em um cenário onde o caráter explicativo de sua formação se mescla às imagens confusas da linguagem infantil. Lá, nada foi separado, desde o início o mundo era um todo que ele, menino, buscava aprender. Sem, entretanto, ansiar compreensões, pôde colher as palavras que "perturbavam / o sentido normal das ideias" e "os sentidos normais da fala". Pegando na bunda do vento, Manoel de Barros foi se formando poeta enquanto se formava gente, enquanto se formava bicho,

115 Mestre em Teoria da Literatura, Universidade Federal de Pernambuco (UFPE). Doutorando em História das Religiões, Universidade de Lisboa, Portugal - leandrodurazzo@gmail.com 
natureza. Nada foi distinguível desde o início, e os poemas iniciais apresentam essa experiência crianceira.

Já nas orelhas dessa edição temos o testemunho do pantaneiro, que se estende pela primeira parte sem nunca perder seu tom. Vemos, nela, as lembranças da Mãe, do Pai e do avô namorador de solidão - e que a deixava destampada, sozinha, sempre que saía da rede para tratar do que quer que fosse. Solidão destampada, imagem que Manoel de Barros mostra muito bem viva, é só uma das formas do mundo desse menino dizer o indizível. Ao lado da Mãe e do Pai, que aparecem grafados com a inicial maiúscula em alguns momentos, tal qual entidades, mitos, está também o menino poeta Bernardo, que acompanha Manoel nas conhecenças dessa vida.

Diz-se de Bernardo o que podemos arriscar dizer do menino Manoel, talvez mesmo do poeta: "Ele fazia parte da natureza como um rio faz, como / um sapo faz, como o ocaso faz". Ele estava lá, era lá, e isso bastava. A impressão que temos é de que Manoel de Barros está, finalmente, explicando como sua visão vê o que sua poesia diz. Através do "Menino do mato" podemos entender algo que o "Caderno de aprendiz" mostrará em experiência linguística, poética, do absoluto indizível. É menino-poeta de olhar oblíquo que tem a linguagem sob domínio, para demonstrar a liberdade absoluta da linguagem poética e da linguagem infantil.

A busca de Manoel de Barros é a da não-palavra, da palavra harmônica que mais faça sentir do que mostrar. É linguagem de criança, cultivada desde a infância, esmerada, simples, direta. Falando de suas lembranças, de sua terra, é como se remontasse a um paraíso que, em vez de perdido, manteve-se para sempre dentro dos olhos de poeta. De olhos úmidos pelas águas do Pantanal — referência e lembrança explícitas - Manoel de Barros chega ao fim da primeira parte de seu livro dizendo das águas que, por essência, são a "epifania da criação". Mostrando como foi criado, deixa ao "Caderno de aprendiz" - composto por trinta e seis poemas — a tarefa mais direta de mostrar o que apreendeu, e como cria, hoje, o eterno menino do mato.

Um menino-poeta e poeta-menino que apreende o substrato do poético a partir das "travessuras", da busca primordial das palavras para recobrar a expressividade literária delas, o "absurdo divino das imagens", de forma que exprimam verdades humanas. Trata-se, já expressou o poeta em poemas de livros anteriores, de chegar à "semente" do ser, às "palavras fontanas" — aquelas que "entoa[m]" Poesia, aquelas nas quais surgem o "desenho verbal da inocência". Esse mergulho no primordial da linguagem metaforiza-se, por indizível, entre outros em versos como esses: "No gorjeio 
dos pássaros tem um perfume de sol?", "Hoje eu vi um passarinho comendo / formigas de pedra!", "Ele viu um passarinho sentado no ombro do arrebol".

A potência da poesia de Manoel de Barros - é o que mais uma vez se presentifica, renovada, na poesia deste Menino do mato - está como a força ancestral dos rios conhecidos, "rios infantis que ainda procuram declives / para escorrer": sempre além do que foi no início, sempre contido na totalidade ingênua da comunhão com a natureza. 